\title{
The Use of Word Walls Technique to Improve Students' Writing Ability in Descriptive Text
}

\author{
Elsa Sovia Mandasari \\ IAIN Bengkulu \\ elsa@gmail.com \\ Syamsul Rizal \\ IAIN Bengkulu \\ syamsulrizal@iainbengkulu.ac.id \\ Nadrah \\ IAIN Bengkulu \\ nadrah@iainbengkulu.ac.id
}

\begin{abstract}
This research is about the use of word walls technique to improve students' writing ability in descriptive text. There are some problems that faced by the students at the seventh grade students of SMPN 17 Kota Bengkulu in writing descriptive text the first is they do not have idea to write descriptive text. Second, they still confused in organizing the writing. Third, they often do some mistakes with the lack of knowledge in vocabularies. The objective of this research was to improve students' writing ability in descriptive text using word walls technique. This research used classroom action research method that consisted of four steps, there are pre-assessment, cycle I, cycle II, and cycle III. The subject of this research was students of Class VII D in SMPN 17 Kota Bengkulu. They were 24 students that consisted of 15 male and 9 female. The instruments of this research were interview, teacher and students' observation checklist, writing test, and documentation. Based on the finding of this research, it showed that word walls technique could improve students' writing ability in descriptive text. Students were active in the classroom and good interaction between teacher and students. The evaluation test administrated at the end of each cycle. The result of mean score on evaluation were pre-assessment $(47,65)$, cycle I $(59,36)$, cycle II $(67,96)$, and cycle III $(73,95)$. It could be concluded that there were improvement in every cycle, a significant different between the mean score of pre-assessment and cycle III namely 47,65 and 73,95. It showed that word walls technique could improve student's writing ability in descriptive text.
\end{abstract}

Keywords: Word Walls Technique, Writing Ability, Descriptive Text

\section{A. Introduction}

This research is about the use of word walls technique to improve students' writing ability in descriptive text. It is generally acknowledged that writing is one of the important skills to be mastered by the students (Hyland, 2002). They use it to communicate to each other, as means of ideas and emotional expression, because when they write their ideas and emotion creatively, they are communicating on paper in their very best way and purposes. Students of Junior High School are required to understand the nature of writing and to produce various functional texts, monologue, and essay in form of procedure, Descriptive, 
narrative, recount, and report text. Regarding to the text types, seventh grade students deals with descriptive and procedure text. Based on Competency Standard- Standar Kompetensi $(S K)$ and Basic Competency- Kompetensi Dasar $(K D)$, the seventh grade students are expected to be able to express meaningful ideas in term of functional text and simple short essay in the form of descriptive and procedure to interact with people in their nearest environment (Depdiknas, 2006). In this thesis, the researcher focused on descriptive text.

According to Wardiman (2008) Descriptive text is one of the functional texts which is difficult enough to be learn by the students. Descriptive text is a text that describes the features of someone, something, or a certain place. Descriptive text consists of introduction and description. Introduction is the part of paragraph that introduces the character, and description is the part of paragraph that describes the character. The students can use the simple present and adjective clause in writing descriptive text. In writing the descriptive text, students often find some difficulties. The students usually feel difficult to organize their ideas. Furthermore, many students made some mistakes and faced difficulties to build and develop their imagination.

Based on the researcher's observation, students' junior high school in SMP 17 Kota Bengkulu have difficult writing ability in descriptive text. Researcher found some problems faced by seventh grade students in junior high school. The first is they do not have idea to write descriptive text. Second, they still confused in organizing the writing. Third, they often do some mistakes with the lack of knowledge in vocabularies. These problems can be influenced by some factors. The researcher assumed these problems appear caused by method or technique in teaching writing, because some teachers taught writing just gave explanation and exercises. It makes the students less comprehending, less interest in writing, and makes students bored. These problems are important to be solved, therefore students get more comprehension in material of writing, students think that writing is an interesting skill, and can continue English material in the next semester.

Teaching English for Junior High School needs appropriate strategy and technique in order that they do not feel bored and they become active in the classroom. To help students' solved these problems, it needs another technique more interesting in teaching writing. One of the techniques is Word Walls. A word wall is a group of words that are displayed on a wall, bulletin board, chalkboard, or whiteboard in a classroom. The words are printed in a large font so that they are easily visible from all student seating areas. It is a teaching tool that teachers use to aid students during reading and writing lessons. Teachers 
use a variety of activities to help students interact with the Word Wall and increase students' ability to read and to write. A Word Wall helps to create a print rich environment for students, and can be a wonderful tool that is designed to promote group learning. Through word wall, students are predicted to be motivated to learn the vocabularies that will be used in reading and writing.

Word wall is simple and easy media to use. It is cheap but interesting. Word walls are used as a tool to teach a language concept. Word walls are successful activities because they focus attention, give ample opportunities for review, and are pleasant for students to use. Kieff (2003) stated that word walls promote independent work habits by providing readily available reference as students complete their reading and writing activity. Word wall media has very useful for students to help them in the process of writing. The new words, unfamiliar words, and their spelling can help them in learning the language. By using word wall media students are expected to be interested in writing activity and explore their abilities in writing descriptive text.

Derived from the exceeding, the researcher focuses on the use of word walls technique to improve students' writing ability in descriptive text. By all the explanation above the researcher decides to conduct the research entitled "The Use of Word Walls Technique to Improve Students' Writing Ability in Descriptive Text (Classroom Action Research at the Seventh Grade Students of SMPN 17 Kota Bengkulu in Academic Year 2016/2017)".

\section{B. Research Methodology}

This research employed a classroom action research. It is called CAR because the research focuses on a particular problem and a particular group of students in a certain classroom. The researcher was using CAR because the researcher would like to solve the problem through direct action. Classroom action research itself is a method of finding out what works best in classroom. It means that classroom action research is an activity that is done by the teacher and another people to improve the quality of teaching process.

According to Arikunto (2006), classroom action research is an action research which is carried out at the classroom aimed to improve learning practice quality.1 Based on the definition above the implementation of classroom action research is enable to give improvement of the quality of teaching and learning of school in education since it can diagnose and solve the problem in teaching learning activity. Furthermore, CAR is a 
sequence research activity, that has purpose to improve social quality, that is done by collecting data or information systematically through four steps: planning, acting, observing, and reflecting.

The instruments of the research used writing test, observation checklist, interview, and documentation. The classroom action research needs the data to support the investigation. There are several ways to collect data like questionnaire, observation, field notes, interview, documentation, and test. The procedure of this research was

The procedure of this research was pre-assesment, cycles. In this case the research implemented This research implemented Spiral Kemmis and Mc. Tanggart developed of concept for action research there were four steps: planning, Action, observing and reflecting. There for, the research follow this model to find out the data. The cycle 1 included planning, action, observation, and reflection. Moreover, the cycle 2 Cycle II would be the same steps as cycle I, its implementation based on the result of cycle I. The cycle 3 The step in cycle III was the formulation of the cycle I. In cycle II, and Cycle III the activities was similar to those in cycle I. There were some emphases due to the revised plans.

The data were obtained from the pre-assessment test and some cycle tests. It used interactive model of data analysis proposed by Miles and Huberman. The data analysis consists of three main components, namely: (1) data reduction; (2) data display; and (3) drawing and verifying conclusion.

\section{Results and Discussion}

\section{Results}

The analysis of this research was conducted through observation process and evaluation of students' writing ability result in each cycle, including pre-assessment and all cycles. Through each cycles we could see that students have been studying hard in decreasing students' problems in writing and improving their writing ability though Word Walls Technique, the students tried to show their best performance in their writing when teaching and learning process of English conducted in classroom. The result in each cycles showed that Word Walls Technique was very effective in improving students' writing ability in Junior High School of SMPN 17 Kota Bengkulu and also in other school. It can be seen through the result of students' writing ability in each cycle. The complete result can be seen and compared in following table: 
Table 4.9 The Result of Percentages Pre-Assessment, Cycle I, II, And III

\begin{tabular}{|c|c|c|c|c|}
\hline Categories & $\begin{array}{c}\text { Pre- } \\
\text { Assessment }\end{array}$ & Cycle I & Cycle II & Cycle III \\
\hline Excellent & $0 \%$ & $0 \%$ & $4,16 \%$ & $12,5 \%$ \\
\hline Good & $0 \%$ & $16,67 \%$ & $37,5 \%$ & $75 \%$ \\
\hline $\begin{array}{c}\text { Average } \\
\text { Po } \\
\text { or }\end{array}$ & $12,5 \%$ & $25 \%$ & $41,67 \%$ & $8,33 \%$ \\
\hline $\begin{array}{c}\text { Very Poor } \\
\text { ne }\end{array}$ & $58,33 \%$ & $12,5 \%$ & $0 \%$ & $4,17 \%$ \\
\hline
\end{tabular}

The evaluation and result in each cycle displayed that Word Walls Technique was effective Technique for students in making them to be active in writing form by using its technique. To know the further information about the effectiveness of Word Walls Technique in teaching descriptive text for students, it can be seen in the chart below:

Figure 3. The Percentages of Students' Writing Skill in All Cycle

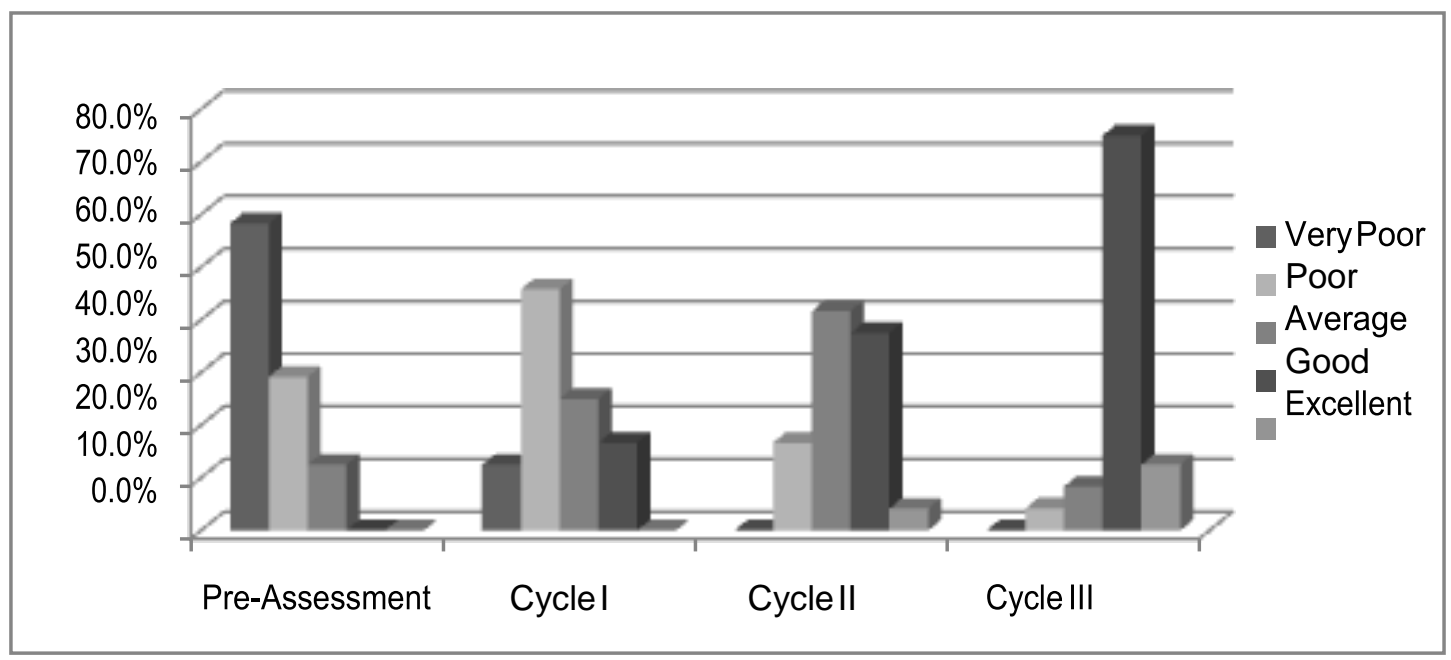

As we can see from the percentages above, it showed us that there were significant progresses in each cycle. The result of mean score on evaluation were pre-assessment $(47,65 \%)$, cycle I $(59,36 \%)$, cycle II $(67,96 \%)$, and cycle III 
$(73,95 \%)$. If it being calculated, the percentages showed us that the mean were 73,95\%. As criteria of minimal comprehensiveness (KKM) at that school SMPN 17 Kota Bengkulu was 70. So the research was success because the mean of the score was upper than 70, and Word Walls technique was good for students in teaching descriptive text in class.

\section{Discussion}

The researcher gave pre-assessment to the students in order to see their writing score, especially in writing descriptive text. After doing the pre-assessment, the researcher concluded that the result was very poor. Therefore, researcher needed to do improvement. That was why researcher did the action in three cycles I, II, and III. After doing cycle I, the researcher found that there was improvement on the students' ability in writing descriptive text. At the beginning, students' average score was $47,65 \%$, while in cycle I was $59,36 \%$. There was improvement almost half of students did not feel bored anymore, although the result was not quite satisfying. Since the indicators of success had not able to use grammar well. They were confused improving content, vocabulary, and mechanics of writing itself.

Therefore, the researcher did cycle II. After doing in cycle II the researcher found that the indicator of success of this research also had not reach yet. Comparing to cycle I, the students' achievement in writing descriptive text in cycle II slightly increased. In cycle I, students average score was 59,36\%, while in cycle II become $67,96 \%$. It was caused by some of the students still found it difficult in using grammar well. They also still confused in punctuation and capitalization. Students looked more interest, creative and little active, also had good motivation. Furthermore, some of them also looked more enthusiastic with the lesson. However, though there was any improvement toward students' writing ability in descriptive text, the target of this research was not still achieved yet.

From the problems above, researcher also felt need to do action again to overcome the problems. Therefore, researcher did cycle III. Cycle III was conducted in the last section. The procedures of the cycle III was the as cycle I and cycle II. From the result above, there was significant on the students' progress. The students seemed interested with the fresh technique in this research which was Word Walls. Moreover, the students had been higher motivation they did not found it difficult on 
whole components of writing which were improving the content, organization, vocabulary, using grammar, mechanics anymore, in this phase, the indicator of the success had been reached. Therefore researcher decided to stop the action.

Based in the result that students had in pre-test, cycle I, II, and III in this research, could be taken some conclusion that the most of the students were interested, motivation, creative and active in learning writing, especially descriptive text by using Word Walls Technique. Then, Kieff stated that word walls promote independent work habits by providing readily available reference as students complete their reading and writing activity ${ }^{1}$. As we can see from the percentages above, it showed us that there were significant progresses in each cycle. The result of mean score on evaluation were pre- assessment $(47,65)$, cycle I $(59,36)$, cycle II $(67,96)$, and cycle III $(73,95)$. If it being calculated, the percentages showed us that the mean were $73,95 \%$. As criteria of minimal comprehensiveness (KKM) at that school SMPN 17 Kota Bengkulu was 70. So the research was success because the mean of the score was upper than 70, and Word Walls technique was good for students in teaching descriptive text in class.

\section{Conclusion and Suggestion}

\section{Conclusion}

. Based on the analysis and the result on the previous chapter, it can be concluded that. In applying Word Walls Technique in teaching writing, it improved teaching and learning process in class especially for seventh grade at SMPN 17 Kota Bengkulu, and it was a good technique in teaching English writing material especially for descriptive text material. Students who had low motivation to write descriptive text and very poor on writing components, after applying this technique they got more motivation in their learning process. Therefore, it was suitable to be applied in teaching writing.

\section{Suggestion}


Based on the conclusion, the researcher would like to offer a suggestion. The English teacher must be able to know the problems that were faced by the students in the teaching and learning process and must be able to solve the problems by choosing appropriate and suitable in teaching in order to reach the purpose of teaching and learning. The English teacher could use Word Walls Technique in English subject especially in teaching writing, so that students could be more motivated, active, and creative in teaching and learning process. It was also hoped this research would be useful for next researcher.

\section{References}

Arikunto, (2006). Procedure Penelitian Suatu Pendekatan Praktek, Jakarta: PT Rineka Cipta.

Arikunto. (2006). Procedure Penelitian Suatu Pendekatan Praktek. Jakarta: PT Rineka Cipta.

Artono, W, et. al. (2008). English in Focus for grade VII Junior high school (SMP/MTs). Jakarta: Pusat Pembukuan, Departemen Pendidikan Nasional.

Decy Anggriani, Improving Students" Vocabulary Achievement Through Word Walls Strategy. Journal of English Language Teaching And Learning of FBS UNIMED. 2(3), 1 .

Depdiknas. (2006). Kurikulum Tingkat Satuan Pendidikan (School Based Curriculum) Standar Isi Mata Pelajaran Bahasa Inggris SMP dan MTS. Jakarta: Badan Standar Nasional Pendidikan.

Henry, R. (2005). Writing Systems: A Linguistic Approach. Oxford: Blackwell Publishing,

Judith K. (2003). Winning Ways with Word Walls, Association for Childhood Education International journal. 80(2), 1.

Hyland, K. (2002). Teaching and Researching Writing. London: Pearson Education. 